\section{Australian Journal of \\ Crop Science}

AJCS

ISSN:1835-2707

AJCS 10(3): 425-433 (2016)

DOI: $10.21475 /$ ajcs.2016.10.03.p7477

\title{
Growth, nutrient concentration and principal component analysis of Cagaita (Eugenia dysenterica DC.) seedlings grown in nutrient solution
}

\author{
Layara Alexandre Bessa $^{1 *}$, Marialva Alvarenga Moreira ${ }^{2}$, Fabiano Guimarães Silva ${ }^{1}$, Clenilso Sehnen \\ Mota $^{3}$, Luciana Cristina Vitorino ${ }^{1}$
}

${ }^{1}$ Instituto Federal Goiano, Câmpus Rio Verde, Rodovia Sul Goiana Km 01, Rio Verde-GO, Brazil

${ }^{2}$ Federal University of Viçosa, Avenue Peter Henry Rolfs, s/n, Viçosa-MG, Brazil

${ }^{3}$ Estadual University of Santa Catarina, Avenue Madre Benvenuta, Itacorubi, Florianópolis-SC, Brazil

*Corresponding author: layara.ifmorrinhos@hotmail.com

\begin{abstract}
Cagaita (Eugenia dysenterica DC.) is a native fruit tree with high economical potential from the Brazilian Cerrado. However, little is known about the essential nutritional demands of its seedlings. To determine the nutrient demands of Cagaita, a greenhouse experiment was performed, in which plants were grown under hydroponic condition to assess the growth (length and diameter of stems, number of leaves, number of nodes, volume and length of roots, area of the leaf and crown and total dry weight of the leaves, stems and roots) and nutrient concentration (N, P, K, Ca, Mg, S, B, Cu, Fe, Mn and $\mathrm{Zn}$ ) at different time points after the plant were transferred into a nutrient solution. The seedling growth presented linear behavior until 180 days after transplantation. The total plant dry weight was $6.54 \mathrm{~g}$ after 180 days of transfer into the nutrient solution. The $\mathrm{N}$ content was positively correlated with the total dry weight and leaf area, whereas B was negatively correlated with the length of the stem and number of leaves. Macro and micronutrient concentrations presented the following order: $\mathrm{N}>\mathrm{Ca}>\mathrm{K}>\mathrm{P}>\mathrm{Mg}>\mathrm{S}$, Fe $>\mathrm{Mn}>\mathrm{B}>\mathrm{Zn}>\mathrm{Cu}$. A principal component analysis of the different sampling times provided important information used to define the growth variables.
\end{abstract}

Keywords: fruit tree; greenhouse; hydroponics; macronutrient; micronutrient.

Abbreviations: DAT_days after transfer, SD_stem diameter, SL_stem length, RV_root volume, RL_root length, NL_number of leaves, NN_number of nodes, LA_leaf area, CA_crown area, LDW_leaf dry weight, SDW_stem dry weight, RDW_root dry weight, TDW_total dry weight, PCA_principal component analysis

\section{Introduction}

The native fruit tree species of the Cerrado have high potential for cultivation in traditional systems. One of such a trees is the cagaita (Eugenia dysenterica DC.), a fruit tree belonging to the family Myrtaceae. The cagaita presents slow growth and medium heights, reaching $5 \mathrm{~m}$ on average at 12 years of age. It primarily grow in the central regions of Brazil and has ornamental, industrial and economic potential (Souza et al., 2008).This species is found in grouped populations, especially in Red-Yellow Latosols that have higher average contents of potassium, calcium, magnesium, manganese and clay compared with other soils, where this species does not occur (Duarte et al., 2006). Although there is a growing potential market for this fruit tree, it is not currently exploited by farmers, which is mainly because of the lack of scientific knowledge on the species because its fruits are primarily collected in an extractive and predatory manner. One of the limiting factors for the production of this species is the largescale production of seedlings and establishment of orchards because there is a limited knowledge on the methods of fertilization, and problems have been observed in relation to nutrient deficiencies or excesses caused by fertilization applied without scientific criteria (Resende et al., 2010). The application of fertilizers in high doses to reach high crop yields is common. However, this practice results in the low use efficiency of the nutrients present in the chemical fertilizers (Zheng et al., 2014). These nutritional demands are limiting factors for the production of native plants, especially for fruit trees such as E. dysenterica. To establish quality seedlings in the field, the appropriate nutritional demand must be determined, especially during the plant's early development. This stage is fundamental for seedling establishment and may enable the large-scale acquisition of trees such as cagaita by farmers, which may occur through production by the farmer or by acquisition through nurseries of native fruit tree species. Many of native trees such as cagaita have potential to endure adverse field conditions and commercialization and have contributed to the recovery of degraded areas.

In general, nutrient uptake follows the pattern of growth curves (dry weight accumulation). The nutrient uptake rates can be expressed as response curves according to plant age. This can also be used to indicate the periods when nutrient uptake is higher and additional nutrients are required. Nutrient response curves are; therefore, important tools for crop management and fertilization (Vidigal et al., 2009). Plant species present specific nutritional demands, and the uptake of different nutrients varies during different vegetative stages. In the present study, we attempted to clarify the cultivation seasons of cagaita plants that have the greatest effect on growth, biomass accumulation and macro and 
micronutrient uptake at the seedling stage of production. The present study aimed to characterize the growth and nutrient accumulation characteristics and analyze the principal components of cagaita seedlings grown in nutrient solution.

\section{Results and Discussion}

\section{Evaluation of plant growth}

Variation in the stem diameter (SD), stem length (SL), root volume (RV), root length (RL), number of leaves (NL), number of nodes (NN), leaf area (LA), crown area (CA) and leaf, stem, root and total dry weight (TDW) according to the sampling time (DAT) are presented in Fig 3 and Fig 4. All of the plant growth parameters increased linearly during the experimental period. The average increase per month was $0.393 \mathrm{~mm}$ for SD, $6.60 \mathrm{~cm}$ for SL, $1.425 \mathrm{~mL}$ for RV, 47.27 $\mathrm{cm}$ for RL, 4.197 units for NL, 2.103 units for NN, 62.348 $\mathrm{mm}^{2}$ for LA and $207.39 \mathrm{~cm}^{2}$ for CA (Fig 3). The highest values for all variables were reached at $180 \mathrm{DAT}$ at $3.17 \mathrm{~mm}$, $37.75 \mathrm{~cm}, 10.78 \mathrm{~mL}, 47.27 \mathrm{~cm}, 22.95$ units, 11.51 units, $327.15 \mathrm{~mm}^{2}$ and $1792.6 \mathrm{~cm}^{2}$ for SD, SL, RV, RL, NL, NN, LA and CA, respectively (Fig 3).

The dry weights at 180 DAT were $2.9466 \mathrm{~g}, 1.3022 \mathrm{~g}, 2.82$ $\mathrm{g}$ and $6.5484 \mathrm{~g}$, and the unit increment of masses of dry matter were $0.0208 \mathrm{~g}, 0.0106 \mathrm{~g}, 0.0142 \mathrm{~g}$ and $0.045 \mathrm{~g}$ (Fig 4) and dry weight accumulation per month were $0.624 \mathrm{~g}, 0.318$ $\mathrm{g}, 0.426 \mathrm{~g}$ and $1.371 \mathrm{~g}$ for the leaf, stem, root and total plant dry matter, respectively. Leaves accounted for most of the dry weight of $E$. dysenterica plants during the initial stage of seedling growth, which may have been related to their role as a sink for nutrients taken up by the plant from the nutrient solution. The source:sink ratio of different crops is an important tool for explaining the potential production of plants (Mendes et al., 2007). Rosane et al. (2013) also observed a higher dry weight percentage for leaves than for stems or roots in star fruit trees. The linear behavior observed for the quantified growth variables may be explained by the early developmental stages, which has been previously observed (Costa et al., 2012; Rosane et al., 2013). In addition, linear growth may have resulted from the availability of nutrients in the nutrient solution during growth because the nutrient solution is a homogeneous medium, in which nutrients are available as ions in adequate amounts (Puga et al., 2010).

\section{Macronutrient concentrations in plant tissues}

The maximum uptake of each nutrient was dependent on the time of seedling transplantation in to the nutrient solution. Nitrogen $(\mathrm{N})$ had the highest concentration at the whole plant level and reached $7.82 \mathrm{~g} \mathrm{~kg}^{-1}$ on average at 180 DAT. This increased uptake may have been caused by the importance of $\mathrm{N}$ for plants. $\mathrm{N}$ is a component of aminoacids and protein and is present in important $\mathrm{N}$ compounds, such as chlorophyll and nucleic acids (Malavolta, 2006). The leaf $\mathrm{N}$ concentration had an average value of $2.97 \mathrm{~g} \mathrm{~kg}^{-1}$ and was not influenced by the sampling time, whereas at the stem and root the highest $\mathrm{N}$ concentrations were 1.62 at $180 \mathrm{DAT}$, and $3.24 \mathrm{~g} \mathrm{~kg}^{-1}$ at 164 DAT, respectively. A higher $\mathrm{N}$ concentration $\left(12.47 \mathrm{~g} \mathrm{~kg}^{-1}\right)$ at 180 DAT was also observed in the shoots of pequi plants (Caryocar brasiliense Camb.) (Carlos et al., 2014). The $\mathrm{N}$ demand of the banana cultivar prata-anã (Musa spp. cv. AAB) is constant during most of its growth cycle, especially at the vegetative stage (Silva et al., 2013). $\mathrm{N}$ is the most important nutrient for drupaceous species; however, in excess, $\mathrm{N}$ may delay fruit tree maturation and decrease qualitative parameters (Rombolà et al., 2012). $\mathrm{N}$ fertilization has been observed to promote the vegetative growth of Prunus armeniaca L., although excess amounts of $\mathrm{N}$ did not increase fruit size and production (Milosevic et al., 2013).

The highest phosphorus (P) concentration occurred in the leaves $\left(0.63 \mathrm{~g} \mathrm{~kg}^{-1}\right)$ at $145 \mathrm{DAT}$, stems $\left(0.47 \mathrm{~g} \mathrm{~kg}^{-1}\right)$ at 180 DAT, and roots $\left(0.57 \mathrm{~g} \mathrm{~kg}^{-1}\right)$ at 159 DAT (Fig 5). The higher accumulation of $\mathrm{P}$ in leaves was likely because of the high $\mathrm{P}$ mobility within the plant (Dominghetti et al., 2014), with P transported from older to younger tissues during $\mathrm{P}$ deficiency. A higher $\mathrm{P}$ concentration in leaves $\left(2.63 \mathrm{~g} \mathrm{~kg}^{-1}\right)$ was also found in 10-week-old Pilea sinofasciata plants grown in non-mineral soils (Zheng et al., 2014).

The highest potassium $(\mathrm{K})$ concentration was observed in the roots at $116 \mathrm{DAT}\left(1.41 \mathrm{~g} \mathrm{~kg}^{-1}\right)$. The highest $\mathrm{K}$ concentration occurred in the leaves $\left(1.32 \mathrm{~g} \mathrm{~kg}^{-1}\right)$ at 180 DAT and stems $\left(1.04 \mathrm{~g} \mathrm{~kg}^{-1}\right.$ ) at $117 \mathrm{DAT}$ (Fig 5). Higher K concentration in roots has been reported in species with underground reserve organs (Cecílio Filho and Peixoto, 2013). $\mathrm{K}$ is the second most important nutrient for a number of plant species. Its concentration in crops varies with the location, year and species as well as according to the uptake of other nutrients. However, differences in $\mathrm{K}$ uptake are also related to the length and density of root hairs (Christian et al., 2014), which may explain the higher $K$ concentration in the roots of E. dysenterica observed in the present study.

Leaf calcium (Ca) concentrations were not influenced by the sampling time and presented an average value of $1.71 \mathrm{~g}$ $\mathrm{kg}^{-1}$. The stem $\left(1.04 \mathrm{~g} \mathrm{~kg}^{-1}\right)$ and root $\left(0.52 \mathrm{~g} \mathrm{~kg}^{-1}\right) \mathrm{Ca}$ concentrations were highest at 66 DAT and 180 DAT, respectively (Fig 5). Ca presented the second-highest concentration in seedlings of $E$. dysenterica, with an average of $3.53 \mathrm{~g} \mathrm{~kg}^{-1}$ for the entire plant (leaf, stem and root). In fruit trees, Ca directly affects fruit quality, softening, stability and shelf life, and low contents result in increased respiration and consequently affect fruit shelf life (Malavolta, 2006; Aular and Natale, 2013). Ca is also considered one of the most important nutrients for plants because it is associated with plant defense, and it may influence the growth, anatomy, morphology and chemical composition of crop species (Nagadze et al., 2014).

Magnesium $(\mathrm{Mg})$ concentrations in the leaves and stem were not influenced by the sampling time and presented average values of 0.44 and $0.36 \mathrm{~g} \mathrm{~kg}^{-1}$, respectively. The root $\mathrm{Mg}$ concentration was highest at 178 DAT $\left(0.29 \mathrm{~g} \mathrm{~kg}^{-1}\right)$ (Fig 5). Nascimento et al. (2011) observed leaf Mg concentrations of $2.70 \mathrm{~g} \mathrm{~kg}^{-1}$ and $2.77 \mathrm{~g} \mathrm{~kg}^{-1}$ in seedlings of the Woodard and Bluebelle cultivars of Vaccinium myrtillus L. grown in semi-hydroponics, respectively.

The whole-plant sulfur (S) concentration (leaf, stem and root) was $0.7146 \mathrm{~g} \mathrm{~kg}^{-1}$ at $180 \mathrm{DAT}$. The roots had the highest $\mathrm{S}$ concentrations at $0.35 \mathrm{~g} \mathrm{~kg}^{-1}$ at $158 \mathrm{DAT}$. Leaf and stem $\mathrm{S}$ concentrations were highest at $137 \mathrm{DAT}\left(0.13 \mathrm{~g} \mathrm{~kg}^{-1}\right)$ and 180 DAT $\left(0.22 \mathrm{~g} \mathrm{~kg}^{-1}\right)$, respectively. The effect of $S$ in plants has received little attention because its limitations are less frequent in agricultural soils; however, S deficiencies have been previously reported (Divito and Sadras, 2014).

Macronutrients concentrations in E. dysenterica seedlings occurred in the following order at 180 DAT: $\mathrm{N}>\mathrm{Ca}>\mathrm{K}>\mathrm{P}>\mathrm{Mg}>\mathrm{S}$. The macronutrient concentration in Averrhoa carambola L. root stocks occurred in the following order: $\mathrm{N}>\mathrm{K}>\mathrm{Ca}>\mathrm{Mg}>\mathrm{S}>\mathrm{P}$ (Rosane et al., 2013). Also the macronutrient concentration in Annona muricata L. seedlings occurred in the following order: $\mathrm{K}>\mathrm{N}>\mathrm{Ca}>\mathrm{Mg}>\mathrm{P}$ (São José et al., 2014). 


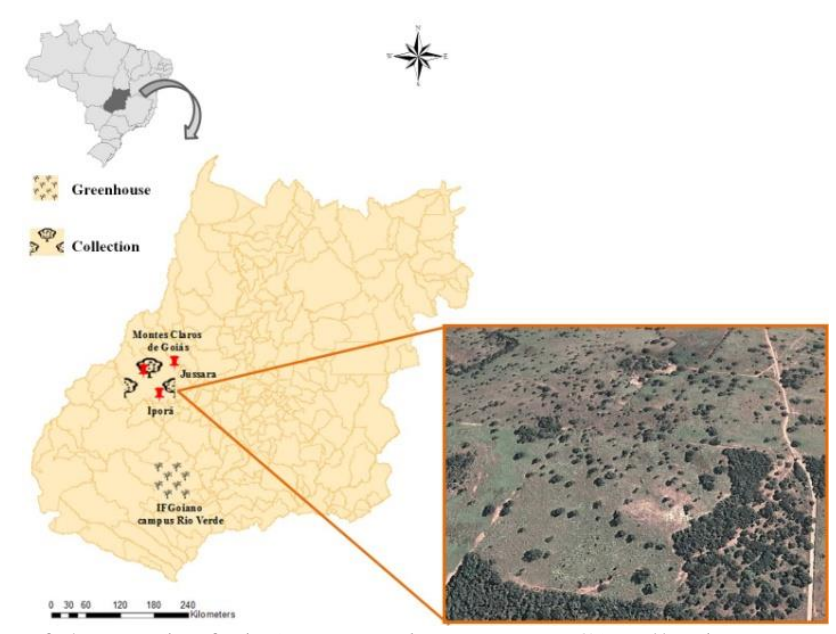

Fig 1. Map showing the location of the cagaita fruit (Eugenia dysenterica DC.) collection area and experimental site. The detailed section shows an aerial view of the vegetation of the collection site (Cerrado strict sensu vegetation).

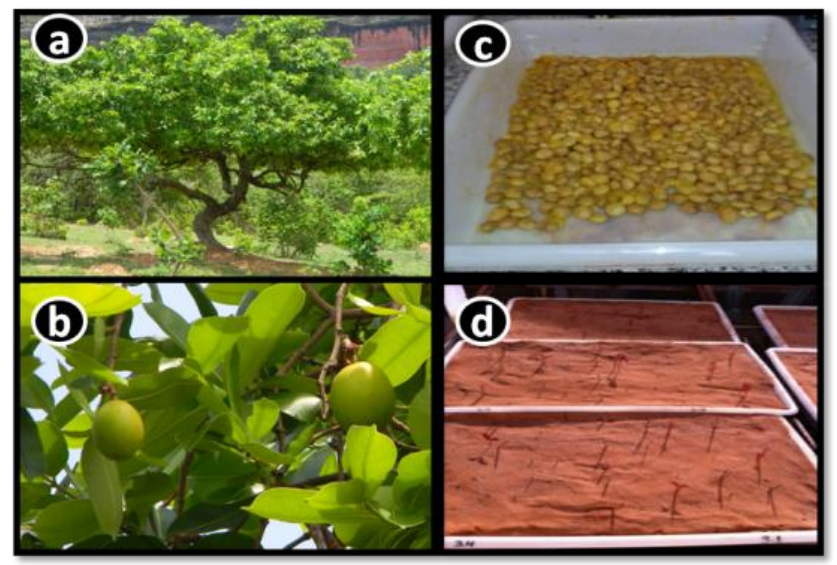

Fig 2. Tree (a), fruit (b), depulped seeds (c) and cagaita seedling (Eugenia dysenterica DC.) emergence in trays containing sand as substrate $(\mathrm{d})$.
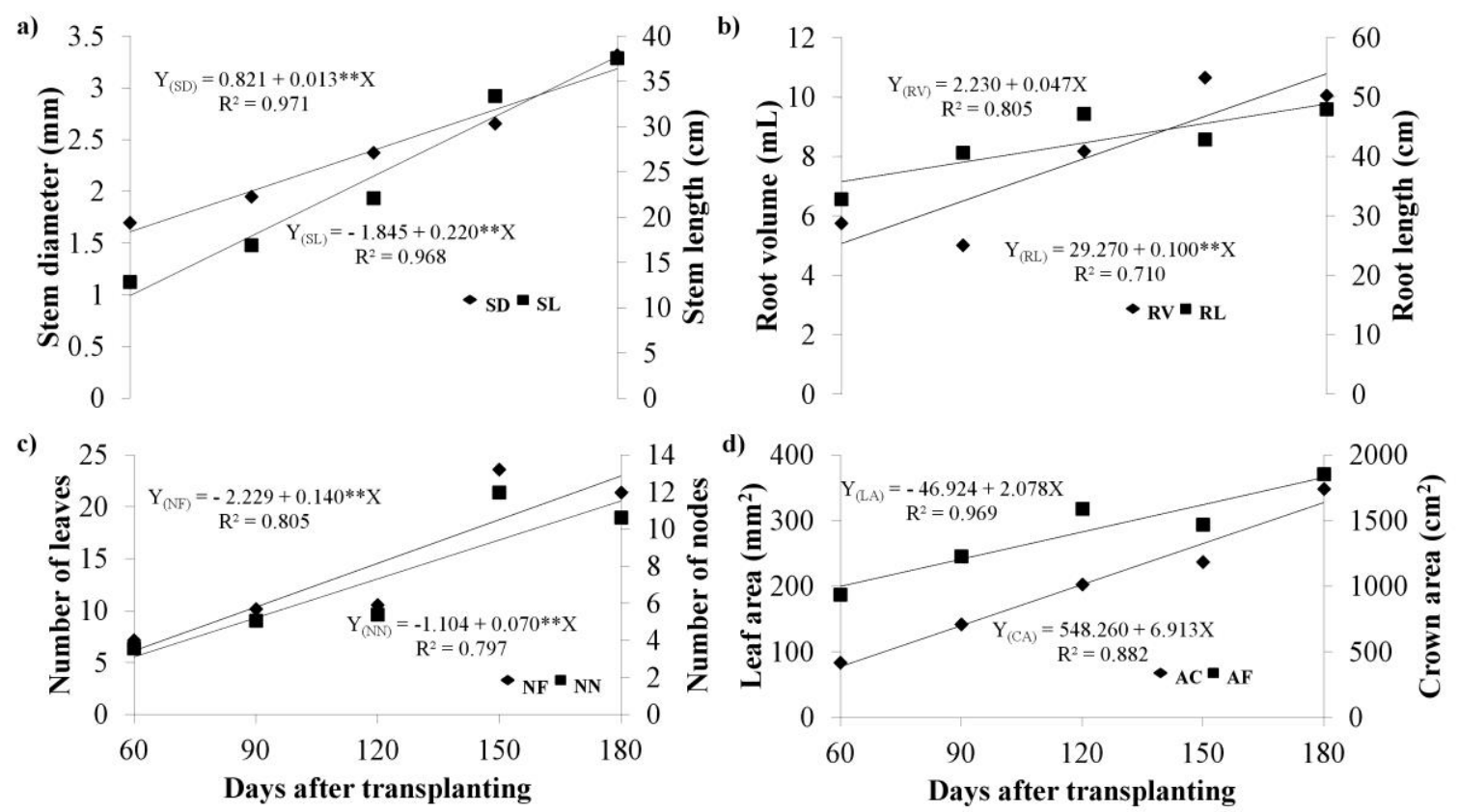

Fig 3. Growth parameters of cagaita (Eugenia dysenterica DC.) seedlings at different days after transplanting: a) stem diameter (SD) and stem length (SL), b) root volume (RV) and root length (RL), c) number of leaves (NL) and number of nodes (NN) and d) leaf area $(\mathrm{LA})$ and crown area $(\mathrm{CA}) * *$ Significant according to the $\mathrm{F}$ test $(\mathrm{p}<0.01)$. 


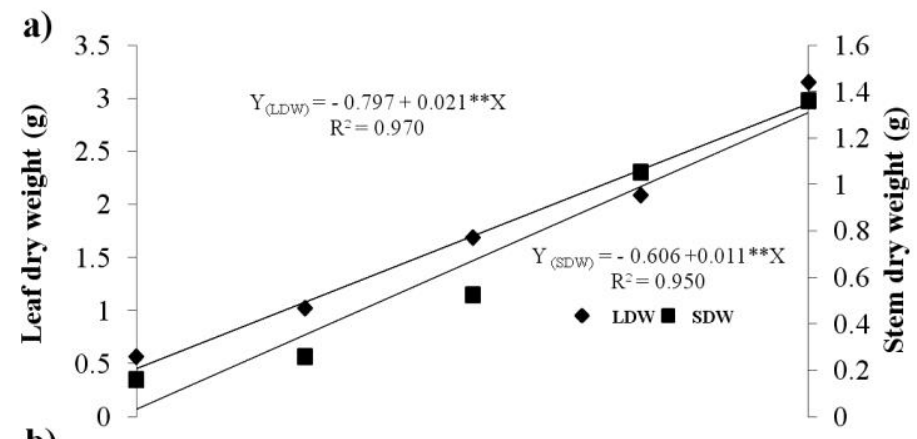

b)

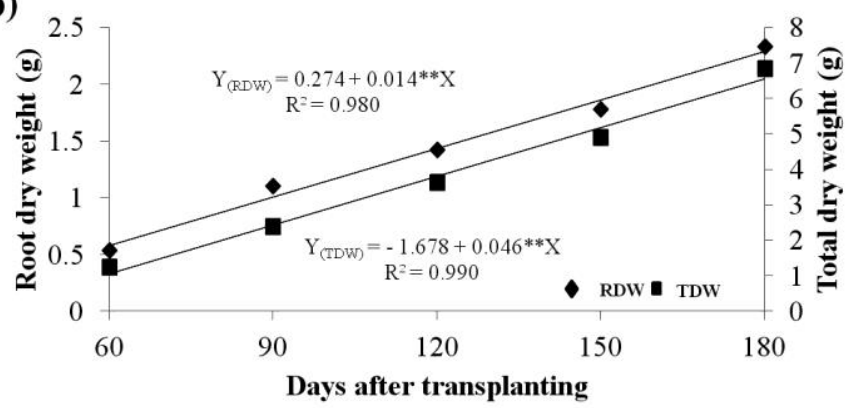

Fig 4. Leaf dry weight (LDW), stem dry weight (SDW), root dry weight (RDW) and total dry weight (TDW), of cagaita (Eugenia dysenterica DC.) seedlings at different days after transplanting. ** Significant according to the $\mathrm{F}$ test $(\mathrm{p}<0.01)$.
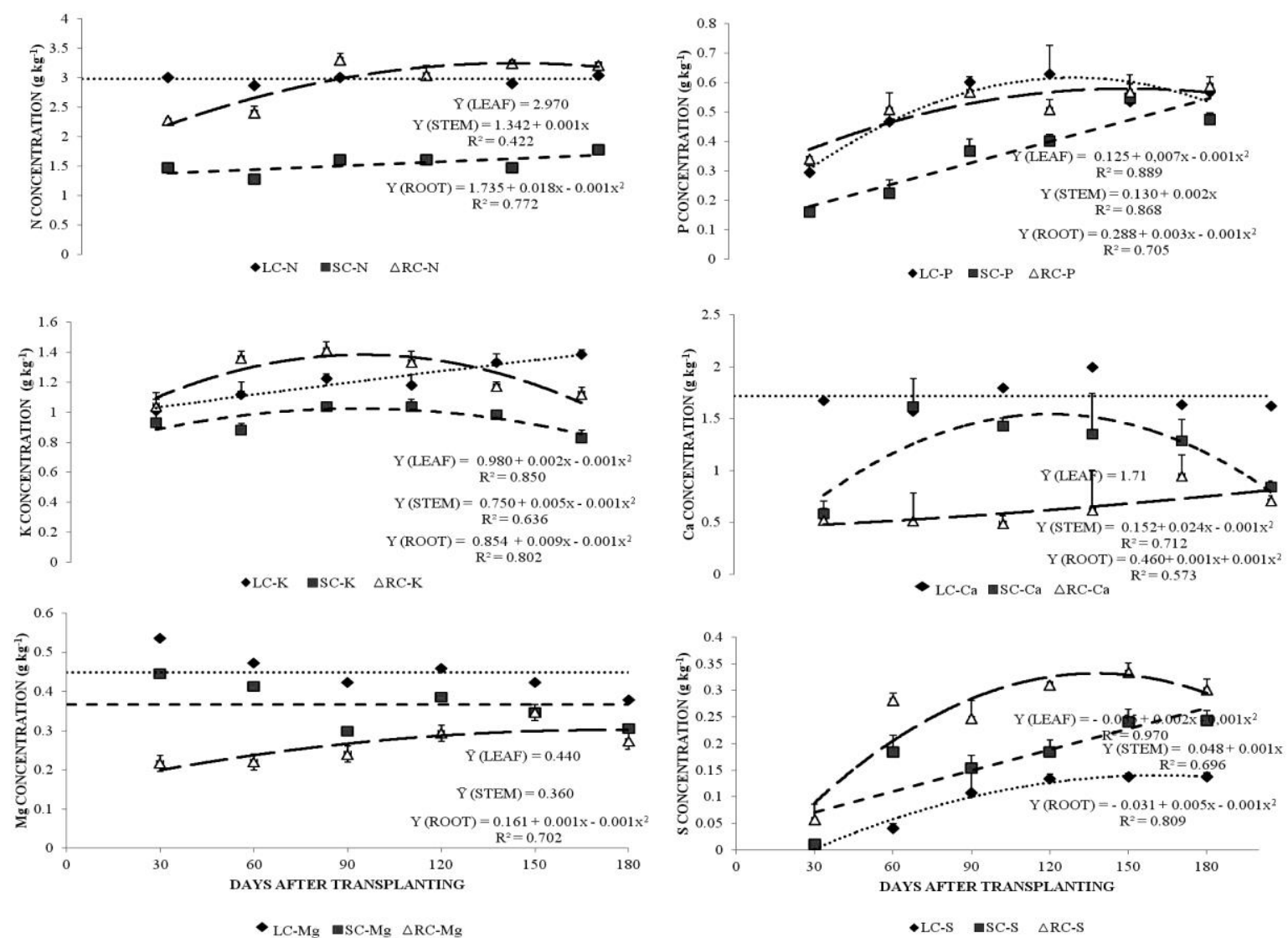

Fig 5. Macronutrient (N, P, Ca, K, Mg and S) concentrations in the leaves, stems and roots of cagaita (Eugenia dysenterica DC) seedlings at different days after transplanting. 

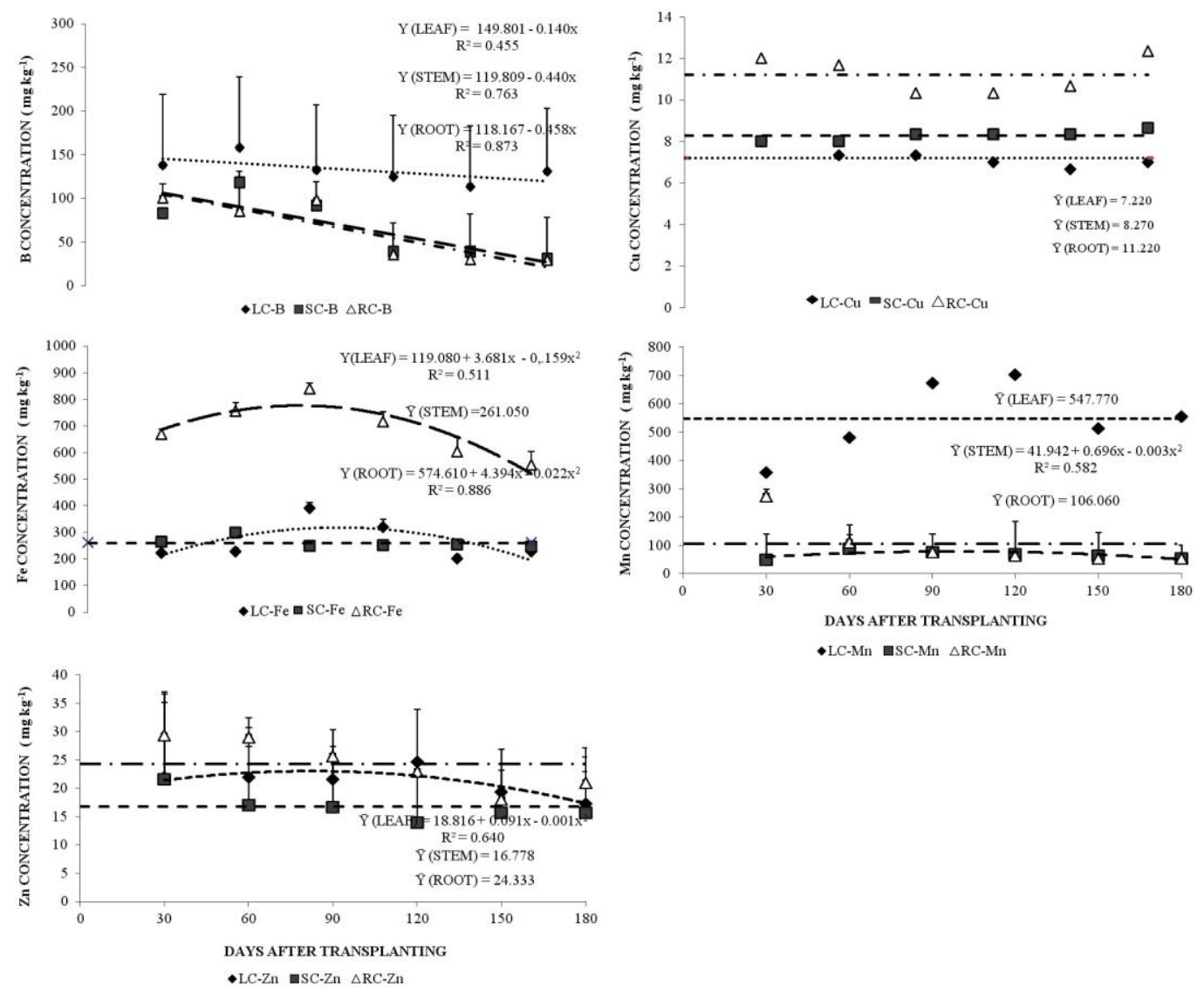

Fig 6. Micronutrient $(\mathrm{B}, \mathrm{Cu}, \mathrm{Fe}, \mathrm{Mn}$ and $\mathrm{Zn}$ ) concentrations in theleaves, stems and roots of cagaita (Eugenia dysenterica $\mathrm{DC}$ ) seedlings at different days after transplanting.
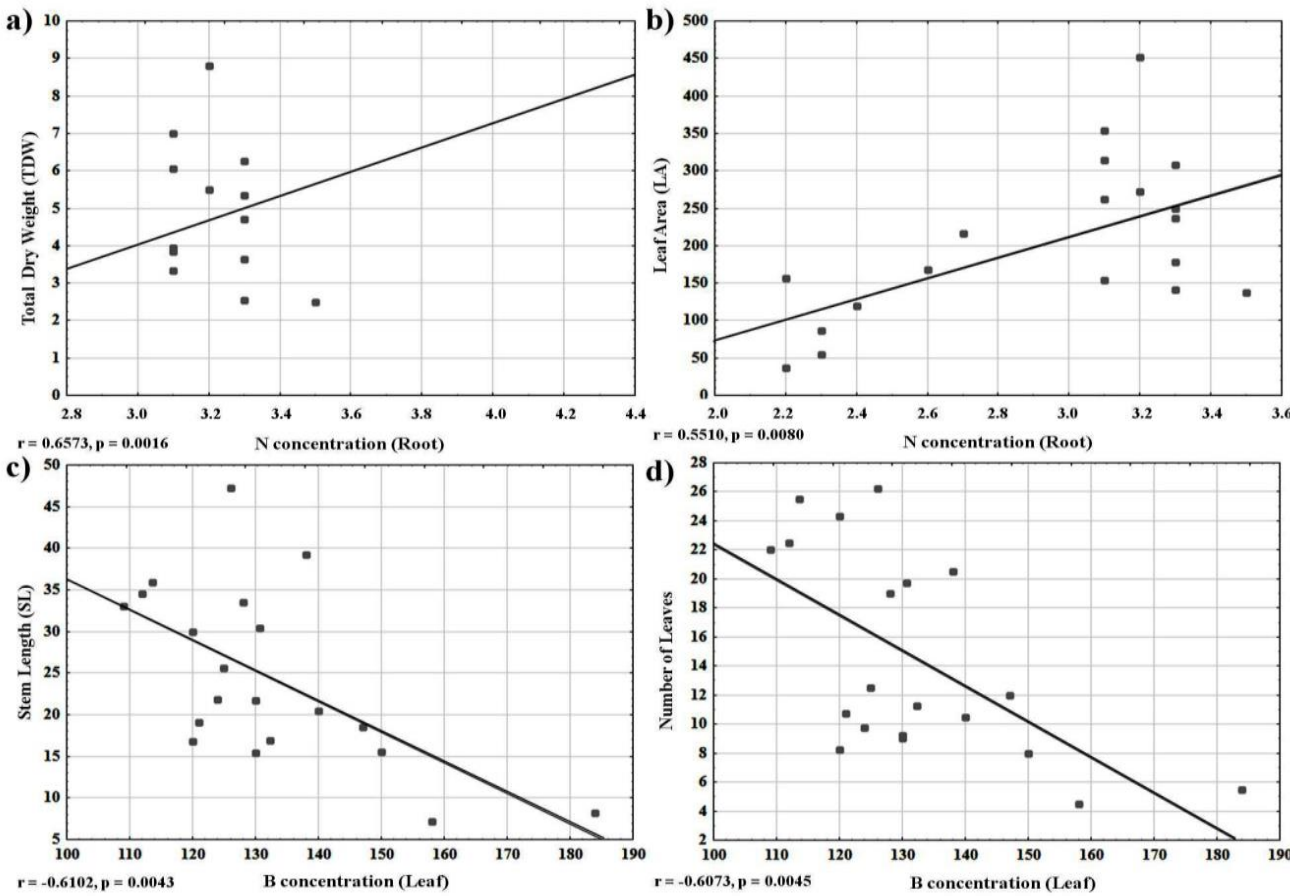

Fig 7. Correlations between the a) total dry weight and root $\mathrm{N}$ concentration; b) leaf area and root $\mathrm{N}$ concentration; c) stem length and leaf boron concentration; and d) number of leaves and leaf boron concentration. 


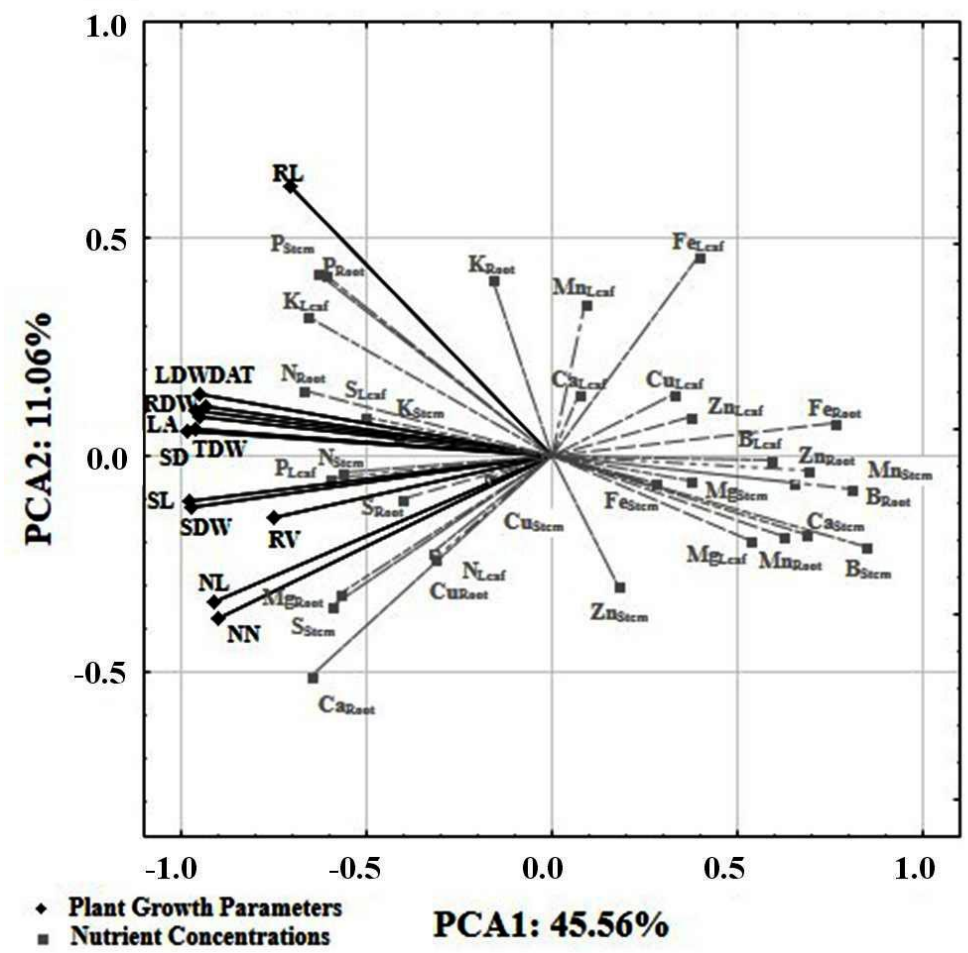

Fig 8. Biplot showing the first two variables of the principal component analysis (PCA1 and PCA2). The black lines are growth parameters evaluated and lines in gray, the concentrations of nutrients found in the tissues of plants of Eugenia dysenterica DC. evaluated. The size of the line is the weight parameter to define the principal component.

\section{Micronutrient concentrations in plant tissues}

The highest boron (B) concentration (124.52 $\left.\mathrm{mg} \mathrm{kg}^{-1}\right)$ was observed in leaves at 180 DAT. For the same sampling time, the B concentrations of the stems and roots were 40.60 and $35.67 \mathrm{mg} \mathrm{kg}^{-1}$, respectively (Fig 6). This higher B accumulation in the leaves was likely because this nutrient is immobile in the plant and does not move from leaves or other organs to meet growth needs (Malavolta, 2006). However, B fertilization was observed to increase the number of new leaves in Prunus persica (L.) Batsch. seedlings, and mobility of B within the plant after leaf application has been observed (Souza et al., 2012). Sá et al. (2014) observed that B soil application increased its concentration in the fruits and leaves of Malus domestica more efficiently compared with leaf application. Copper $(\mathrm{Cu})$ concentrations for all plant parts were not affected by the sampling time, with average values of $7.22 \mathrm{mg} \mathrm{kg}^{-1}$ in leaves, $8.27 \mathrm{mg} \mathrm{kg}^{-1}$ in stems and $11.22 \mathrm{mg}$ $\mathrm{kg}^{-1}$ in roots (Fig 6). However, a tendency towards higher $\mathrm{Cu}$ concentration was observed in roots. Plants most likely take up $\mathrm{Cu}$ as $\mathrm{Cu}^{+}$or $\mathrm{Cu}^{+2}$, which have low mobility until tissue senescence, which results in delayed translocation into the shoot and consequently $\mathrm{Cu}$ accumulation in the root (Lehmann and Rillig, 2015).

Iron $(\mathrm{Fe})$ levels in the stem were not influenced by the sampling time and had an average value of $261.05 \mathrm{mg} \mathrm{kg}^{-1}$. $\mathrm{Fe}$ concentrations were higher in the roots, with the highest value $\left(648 \mathrm{mg} \mathrm{kg}^{-1}\right)$ at $180 \mathrm{DAT}$. The highest leaf $\mathrm{Fe}$ concentration $\left(332.23 \mathrm{mg} \mathrm{kg}^{-1}\right.$ ) was observed at $115 \mathrm{DAT}$ (Fig 6). Among the micronutrients, Fe presented the highest average concentration (1175.82 $\mathrm{mg} \mathrm{kg}^{-1}$ ) until 180 DAT (leaf, stem and roots). Certain species of fruit trees, e.g., Citrus aurantium L. and Citrus limonia Osb, present high tolerance to the absence of $\mathrm{Fe}$, although their hybrids may present sensitivity to $\mathrm{Fe}$ availability (Gama et al., 2015). Fe uptake by the roots is directly related to the uptake of other nutrients, such as $\mathrm{Cu}$ and $\mathrm{Zn}$ (Pestana et al., 2013; Gama et al., 2015).

The manganese $(\mathrm{Mn})$ concentration at the whole plant level (leaf, stem and roots) was $658.18 \mathrm{mg} \mathrm{kg}^{-1}$ at $180 \mathrm{DAT}$, and an influence of sampling time was not observed, with the overall average at $547.77 \mathrm{mg} \mathrm{kg}^{-1}$. There was a tendency for higher Mn concentration in leaves. The highest Mn concentration in the stem was observed at 111 DAT $\left(111.83 \mathrm{mg} \mathrm{kg}^{-1}\right)$ and for roots the average concentration was $106.06 \mathrm{mg} \mathrm{kg}^{-1}$ (Fig 6). In $A$. carambola, the highest Mn concentration was observed in roots following 120 days of cultivation $(211 \mathrm{mg}$

$\left.\mathrm{kg}^{-1}\right)$, and the lowest was observed in the stems $\left(53 \mathrm{mg} \mathrm{kg}^{-1}\right)$ and leaves (175 $\mathrm{mg} \mathrm{kg}^{-1}$ ) (Hernandes et al., 2011).

The highest zinc $(\mathrm{Zn})$ concentration was observed in roots and stems, having average of $24.33 \mathrm{mg} \mathrm{kg}^{-1}$ and $16.78 \mathrm{mg} \mathrm{kg}$ ${ }^{1}$, respectively. The highest $\mathrm{Zn}$ concentrations in the leaves (23.3 $\mathrm{mg} \mathrm{kg}^{-1}$ ) were observed at 98 DAT (Fig 6). A high concentration of $\mathrm{Zn}$ in roots may affect the growth of certain plants. Marichali et al. (2014) observed a suppression of root elongation because of excess $\mathrm{Zn}$ in Coriandrum sativum $\mathrm{L}$., which may be associated with a significant loss of cell viability at the root tip. In cagaita fruits, micronutrient concentration presented the following order of demand at 180 DAT: $\mathrm{Fe}>\mathrm{Mn}>\mathrm{B}>\mathrm{Zn}>\mathrm{Cu}$. Micronutrients in fruits of Olea europaea. L. cv Picholine have been reported to accumulate in the following order: $\mathrm{Fe}>\mathrm{B}>\mathrm{Zn}>\mathrm{Mn}$ (Tekaya et al., 2014).

\section{Nitrogen and boron correlation with growth variables}

All of the quantified variables were correlated. The growth parameters presenting the highest correlation coefficients were also correlated, e.g., LA $\times$ leaf dry weight $(r=0.99)$, SL $\times \mathrm{NL}(\mathrm{r}=0.93), \mathrm{NN} \times \mathrm{NL}(\mathrm{r}=0.97)$. Nutrient concentrations were correlated with the growth parameters; however, lower correlation coefficients were obtained (Fig 7). The TDW and 
LA were positively correlated with root $\mathrm{N}$ concentration (Fig 7); thus, as the root $\mathrm{N}$ concentration increased, the TDW and LA also increased. $\mathrm{N}$ concentration and leaf expansion are directly related to vegetative growth (Ata-Ul-Karim et al., 2014). Thus, LA has been used as a new indicator of $\mathrm{N}$ in crops (Zhao et al., 2014). Studies of Ricinus communis L. showed that increasing $\mathrm{N}$ application rates resulted in increased LA and dry weight (Lima et al., 2014). Other correlations were negative, such as those for SL and NL with leaf B concentration (Fig 7); thus, SL and NL decreased with increasing B concentrations. A negative correlation between leaf $\mathrm{B}$ concentration and growth/productivity may have occurred because of the difficulty in removing B from the leaf cuticle or pectic layer of the cell wall, which does not perform metabolic functions, leading to an over estimation of leaf B concentrations (Boaretto et al., 1997). In addition, no evidence was observed to support a detrimental role of this nutrient on plant development through the interruption of metabolic processes or changes to the stability of the cell wall (Reid, 2010). The B may have a high affinity for several main metabolites, such as ribose, and likely forms strong complexes with these metabolites; thus inactivating them. This reaction suggests that excess B may interfere with transcription/translation and consequently cell division and expansion in certain plants (Nozawa et al., 2006). B is associated with IAA oxidase activity and could form complexes with their inhibitors, leaving free this enzyme to oxidize the IAA, regulating their endogenous levels (Jarvis et al., 1983). Therefore, it is suggested that B content can influence the concentrations of auxin in plants and consequently their growth.

\section{Principal component analysis}

A principal component analysis (PCA) was performed to clarify the relationship between the different evaluated variables, and the results are presented in Fig 8. The PCA1 and PCA2 explained $45.56 \%$ and $11.06 \%$ of the total variance, respectively. In the plot, the weights of the different variables are presented with arrows and are shown to vary with distance from the origin. The different growth parameters and sampling times, referred to as DAT, were observed to have the same approximate weight in the definition of the scores, except for RV, which had a lower weight. All of the nutrient concentrations presented lower weights than the growth variables; thus, they contributed less to explain the data variance. The biplot enabled the evaluation of the correlation level among the quantified variables, with lines presenting the same direction being more closely correlated. All of the growth parameters were disposed in the opposite direction to a significant proportion of the nutrient concentrations; thus, growth parameters were better correlated with each other than with nutrient concentrations. Variables such as DAT, LA, RDW (root dry weight), TDW and SD were similar and were highly correlated. However, N, P, K and S concentrations were highly correlated with the growth. Root $\mathrm{Ca}$ concentrations were also positively correlated with the quantified growth parameters. Cambrollé et al. (2015) observed that the Ca concentration in plant tissues was positively correlated with the reproductive capacity and seeds per fruit in Glaucium flavum Crantz. The concentrations of certain micronutrients, such as $\mathrm{Zn}, \mathrm{B}, \mathrm{Cu}, \mathrm{Fe}$ and $\mathrm{Mn}$, were negatively correlated with the growth parameters, suggesting that these nutrients may have been supplied in amounts exceeding the beneficial threshold for the growth of E. dysenterica. Nutrient excess may directly affect plant growth and physiology (Malavolta,
2006). High quantities of metals such as $\mathrm{Zn}$ and $\mathrm{Cu}$ may induce oxidative stress, resulting in changes in the capacity of certain antioxidant enzymes, such as catalase, peroxidase, superoxide dismutase, as well as glutathione-ascorbate cycle enzymes (Remans et al., 2012). Woody plants such as Populus cathayana Bartr present symptoms of micronutrient toxicity (e.g., Mn) from doses as low as $5 \mathrm{mM}$ (Lei et al., 2007). However, Vitis vinifera Linn. can tolerate Mn stress between 15-30 $\mathrm{mM}$ without presenting pronounced decreases in LA and NL (Yao et al., 2012), indicating that this species is tolerant to high levels of Mn. However, specific studies are needed to establish the toxic nutrient levels for $E$. dysenterica. We suggest further plant growth studies for this species to evaluate nutrient concentrations in other developmental stages, because the sampling time (DAT; 30 , $60,90,120,150$ and 180 days) as well as the principal components (PCA1 and PCA2) significantly explained most of the analyzed variables. Therefore, the sampling time and principal components were effective in explaining the growth parameters and many of the nutrient concentrations.

\section{Materials and Methods}

\section{Obtaining plant material and cultivation in nutrient} solution

The experiment was conducted in a greenhouse at the Laboratory of Plant Tissue Culture (Laboratório de Cultura de Tecidos Vegetais) of the Federal Institute of Goiás (Instituto Federal Goiano), Rio Verde Campus (17 48, 15.9' S, 50 54 ' 19.5" W) between February and August 2012. The Cagaita fruits were collected from the Gameleira Farm, which is located at the municipality of Montes Claros, Goiás, Brazil (16 06'20” S, 51 ${ }^{\circ} 17^{\prime} 11^{\prime} \mathrm{W}, 592 \mathrm{~m}$ altitude) (Fig 1).

Fruits were collected from five to eight matrix plants located in close proximity in the permanent preservation area of the farm. For pulping and seed collection, the fruits were macerated manually on sieves and washed under running water for seed separation. Damaged seeds were discarded, and intact seeds were surface sterilized with $5 \%$ commercial sodium hypochlorite for 3 minutes, washed in distilled water and placed in trays covered with towel paper at ambient temperatures for the removal of excess water. Following pulping, the seed tegument was removed to speed up and standardize germination and seedling formation. Sowing was performed on plastic trays $(50 \times 35 \times 8 \mathrm{~cm})$ containing washed sand as substrate (Fig 2). Thirty days following sowing, when the seedlings presented three to four fully expanded leaves, the plants were transferred to eight liter pots containing halfstrength Hoagland and Arnon (1950) nutrient solution for 45 days.

Plants were grown under an average irradiance of 230

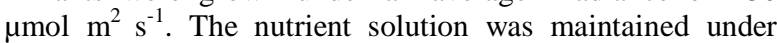
constant aeration by compressed air, and the $\mathrm{pH}$ was adjusted daily to $5.5 \pm 0.5$ by the addition of $\mathrm{HCl}$ or $\mathrm{NaOH}$ as needed. The nutrient solution was changed when electrical conductivity presented a $30 \%$ decrease from its initial value. A randomized block experimental design was used, with six treatments and four replicates per treatment. Each treatment had a different sampling time occurring in 30-day intervals beginning with seedling transference into the nutrient solution (e.g., 30, 60, 90, 120, 150 and 180 days after transplanting). Each experimental plot consisted of one eight liter pot containing nutrient solution and two plants. 


\section{Measurement of traits}

At $60,90,120,150$ and 180 days after transfer (DAT) into the nutrient solution, the following plant growth parameters were determined: length and diameter of the stem, number of leaves, number of nodes, volume of the roots, length of the largest root and area of the leaf and crown. Leaf area was measured by analyzing leaf images using Image $J$ openaccess software (http://rsbweb.nih.gov/ij/download.html) (Ferreira and Rasband, 2010). The plants were harvested and separated into leaf, stem and root samples, which were dried in a forced-air circulation oven at $65^{\circ} \mathrm{C}$ until a constant weight was reached, and the dry weights were then measured. Following drying, the samples harvested at the different evaluated sampling times $(30,60,90,120,150$ and 180 days after transplanting) and were ground using a Wiley-type Mill equipped with a 20 mesh sieve Then the nutrient concentrations were determined $(\mathrm{N}, \mathrm{P}, \mathrm{K}, \mathrm{Ca}, \mathrm{Mg}, \mathrm{S}, \mathrm{Fe}, \mathrm{Cu}$, $\mathrm{Zn}, \mathrm{B}$ and $\mathrm{Mn}$ ) according to Malavolta et al. (1997).

\section{Statistical analyzes}

The obtained data were subjected to variance and regression analyses using Sisvar 5.3 software (Ferreira, 2010). Regression models were selected based on the highest coefficients of determination and significance of the regression coefficients according to the t-test at $p \leq 0.05$. Because of the large number of parameters quantified in the experiment and high level of correlation among them, a principal component analysis was performed to decrease the number of variables (Wold et al., 1987; Jeong et al., 2015). Different variables were also evaluated depending on the sampling time (DAT) and principal components. These analyses were performed using the $\mathrm{R}$ statistics package ( $\mathrm{R}$ Core Team, 2013). The normality of the residuals was confirmed using the Shapiro-Wilk test.

\section{Conclusion}

The growth of $E$. dysenterica seedlings varied linearly until 180 DAT. The TDW of the seedlings was $6.54 \mathrm{~g}$ at the end of the experiment. The $\mathrm{N}$ was positively correlated with TDW and LA, whereas B was negatively correlated with SL and NL. The macronutrient and micronutrient concentrations were observed in the following order: $\mathrm{N}>\mathrm{Ca}>\mathrm{K}>\mathrm{P}>\mathrm{Mg}>\mathrm{S}$ and $\mathrm{Fe}>\mathrm{Mn}>\mathrm{B}>\mathrm{Zn}>\mathrm{Cu}$, respectively. Two principal components (PCA1 and PCA2) explained $56.65 \%$ of all variation. The principal component analysis of the sampling times (DAT) was important and could define most of the analyzed parameters, especially the growth parameters.

\section{Acknowledgements}

The authors wish to thank the Research Foundation of the State of Goiás (Fundação de Amparo à Pesquisa do Estado de Goiás- FAPEG) for the Ph.D. scholarship and the National Council for Scientific and Technological Development (Conselho Nacional de Desenvolvimento Científico e Tecnológico - CNPq) and Brazilian Federal Agency for the Support and Evaluation of Graduate Education (Coordenação de Aperfeiçoamento de Pessoal de Nível Superior- CAPES) for the post-doctorate fellowship (001/2010 MEC/CAPES) and $(26 / 2010 \mathrm{MCT} / \mathrm{CNPq} / \mathrm{CT})$; these awards constituted the financial support for this study.

\section{References}

Ata-Ul-Karim ST, Zhu Y, Yao X , Cao W (2014) Determination of critical nitrogen dilution curve based on leaf area index in rice. Field Crop Res. 167: 76-85.

Aular J, Natale W (2013) Nutrição mineral e qualidade do fruto de algumas frutíferas tropicais: goiabeira, mangueira, bananeira e mamoeiro. Rev Bras Frutic. 35: 1214-1231.

Boaretto AE, Tiritan CS, Muraoka T (1997) Effects of foliar applications of boron on citrus fruit and on foliage and soilboron concentration. In: Bell RW, Rerkasem B (eds) Boron in Soils and Plants, Kluwer Academic Publishers, p 121-123.

Cambrollé J, Muñoz-Vallés S, Mancilla-Leyton JM, Andrades-Moreno L, Lugue T, Figueroa MF (2015) Effects of soil physicochemical properties on plant performance of Glaucium flavum Crantz. Plant Soil. 386: 183-193.

Carlos L, Venturin N, Macedo RLG, Higashikawa EM, Garcia MB, Farias ES (2014) Crescimento e nutrição mineral de mudas de pequi sob efeito da omissão de nutrientes. Cienc Florest. 24: 13-21.

Cecílio Filho AB, Peixoto FC (2013) Acúmulo e exportação de nutrientes em cenoura 'forto' Rev Caatinga. 26: 64-70.

Christian Z, Senbayram M, Peiter E (2014) Potassium in agriculture - Status and perspectives. J Plant Physiol. 171: 656-669.

Costa FS, Suassuna JF, Melo AS, Brito ME, Mesquita EF (2012) Crescimento, produtividade, e eficiência no uso da água em bananeira irrigada no semi-árido paraibano. Rev Caatinga. 25: 26-33.

Divito GA, Sadras VO (2014) How do phosphorus, potassium and sulphur affect plant growth and biological nitrogen fixation in crop and pasture legumes? A metaanalysis. Field Crop Res. 156: 161-171.

Dominghetti AW, Scalco MS, Guimarães RJ, Silva DRG, Carvalho JPS, Pereira V (2014) Doses de fósforo e irrigação na nutrição foliar do cafeeiro. Rev Bras Eng Agr Amb. 18: 1235-1240.

Duarte EF, Naves RV, Borges JFLD, Guimarães NNR (2006) Germinação e vigor de sementes de cagaita (Eugenia dysenterica MART. ex DC.) em função de seu tamanho e tipo de coleta. Pesqui Agropecu Trop. 36: 173-179.

Ferreira DF (2010) SISVAR - Sistema de análise de variância. Versão 5.3. Lavras-MG: UFLA.

Ferreira T, Rasband W (2010) O ImageJ Guia do UsuárioVersion1.43. Available: http://rsbweb.nih.gov/ij/do cs/user-guide.pdf (accessed 2015 may).

Gama F, Saavedra T, Díaz I, Campillo MC, Varennes A, Pestana M, Correia PJ (2015) Fe deficiency induction in Poncirus trifoliata rootstock growing in nutrient solution changes its performance after transplant to soil. Sci Hortic. 182: 102-109.

Hernandes A, Cazetta JO, Natale W, Rozane DE, Souza HA, Romualdo LM (2011) Fracionamento de manganês acumulado nos tecidos de mudas de caramboleira. Rev Bras Cienc Solo. 35: 1679-1685.

Hoagland D, Arnon DI (1950) The water culture method for growing plants without soil. California Agriculture Experimental Station Circular 347. College of Agriculture, University of California, Davis, California, USA.

Jarvis BC, Ali AHN, Shaheed AI (1983) Auxin and boron interrelation to the rooting response and ageing of mung bean cutting. New Phytol. 95: 509-518. 
Jeong SW, Kim GS, Lee GS, Kim Y, Kang NJ, Jin JS, Lee GM, Taek SK, El-Aty AA, Jae-Shim H, Shin SC (2015) The effects of different night-time temperatures and cultivation durations on the (poly) phenolic contents of lettuce: Application of principal component analysis. J Adv Res. 6: 493-499.

Lehmann A, Rillig MC (2015) Arbuscular mycorrhizal contribution to copper, manganese and iron nutrient concentrations in crops - A meta-analysis. Soil Biol Biochem. 81: 147-158.

Lei Y, Korpelainen H, Li C (2007) Physiological and biochemical responses to high Mn concentrations in two contrasting Populus cathayana populations. Chemosphere. 68: 686-694.

Lima GS, Nobre RG, Gheyi HR, Soares LA, Lourenço GS, Silva SS (2014) Aspectos de crescimento e produção da mamoneira irrigada com águas salinas e adubação nitrogenada. Rev Bras Eng Agr Amb. 18: 615-622.

Malavolta E, Vitti GC, Oliveira AS (1997) Avaliação do estado nutricional das plantas: princípios e aplicações. Potafós, Piracicaba, p 319.

Malavolta E (2006) Manual de nutrição mineral de plantas. Livroceres, São Paulo, p. 638

Marichali A, Dallali S, Ouerghemmi S, Sebi H, Hosni K (2014) Germination, morpho-physiological and biochemical responses of coriander (Coriandrum sativum L.) to zinc excess. Ind Crop Prod. 55: 248-257.

Mendes RMS, Távora FJA, Nogueira RJMC, Pitombeira JB (2007) Relações fonte-dreno em feijão-de-corda submetido à deficiência hídrica. Rev Ciênc Agron. 38: 95-103.

Milosevic T, Milosevic N, Glisic I, Bošković-Rakočević L, Milivojević J (2013) Fertilization effect on trees and fruits characteristics and leaf nutrient status of apricots which are grown at Cacak region (Serbia). Sci Hortic. 164: 112-123.

Nagadze E, Coutinho TA, Icishahayo D, Waals JEV (2014) Effect of calcium soil amendments on phenolic compounds and soft rot resistance in potato tubers. Crop Prot. 62: 4045 .

Nascimento DC, Schuch MW, Peil RMN (2011) Crescimento e conteúdo de nutrientes minerais em mudas de mirtileiro em sistema convencional e semi-hidropônico. Rev Bras Frutic. 33: 1155-1161.

Nozawa A, Miwa K, Kobayashi M, Fujiwara T (2006) Isolation of Arabidopsis thaliana cDNAs that confer yeast boric acid tolerance. Biosci Biotechnol Biochem. 70: 17241730.

Pestana M, Correia PJ, Saavedra T, Gama F, Dandlen S, Varennes NA (2013) Root ferric chelate reductase is regulated by iron and copper in strawberry plants. J Plant Nutr. 36: 2035-2047.

Puga AL, Prado RM, Correia MAR, Almeida TB (2010) Omissão de macronutrientes no crescimento e no estado nutricional da chicória cultivada em solução nutritiva. Rev Agrarian. 3: 52-62.
R Core team (2013) R: A language and environmental for statistical computing. $\mathrm{R}$ Foundation for Statistical Computing, Viena, Austria. URL http://www.Rproject.org/.

Reid, R (2010) Can we really increase yields by making crop plants tolerant to boron toxicity? Plant Sci. 178: 9-11.

Remans T, Opdenakker K, Guisez Y, Carleer R, Schat R, Vangronsveld J, Cuypers A (2012) Exposure of Arabidopsis thaliana to excess $\mathrm{Zn}$ reveals a $\mathrm{Zn}$-specific oxidative stress signature. Environ Exp Bot. 84: 61-71.

Resende CFA, Fernandes EP, Silva MF, Leandro WM (2010) Crescimento e acúmulo de nutrientes em mudas cítricas cultivadas em ambiente protegido. Biosci J. 26: 367-375.

Rombolà AD, Sorrenti G, Marodin GAB, Pieri AZ, Barca E (2012) Nutrição e manejo do solo em fruteiras de caroço em regiões de clima temperado. Semin Ciênc Agrar. 33: 639-654

Rosane DE, Prado RM, Natale W, Romualdo LM, Franco CF (2013) Caracterização biométrica e acúmulo de nutrientes em porta-enxertos de caramboleira cultivada em solução nutritiva. Rev Ciênc Agron. 44: 424-436.

São José AR, Prado NB, Bomfim MP, Rebouças TNH, Mendes HTA (2014) Marcha de absorção de nutrientes em anonáceas. Rev Bras Frutic. 36: 176-183.

Silva IP, Silva JTA, Carvalho JG (2013) Nitrogênio e boro em mudas de bananeira Prata Anã cultivadas em casa de vegetação. Rev Agrarian. 6: 51-59.

Souza EB, Naves RV, Borges JD, Vera R, Fernandes EP, Silva LB, Trindade MG (2008) Fenologia de cagaiteira (Eugenia dysenterica DC.) no estado de Goiás. Rev Brase Frutic. 30: 1009-1014

Souza JA, Canesin RCFS, Buzetti S (2012) Mobilidade de boro em mudas de pessegueiro. Rev Bras Frutic. 34: 930935.

Tekaya M, Mechrj B, Cheheb H, Attia F, Chraief H, Avachi M, Boujneh D, Hammamj M (2014) Changes in the profiles of mineral elements, phenols, tocopherols and soluble carbohydrates of olive fruit following foliar nutrient fertilization. LWT-Food Sci Tech. 59: 1047-1053.

Vidigal SM, Pacheco DD, Costa EL, Facion CE (2009) Crescimento e acúmulo de macro e micronutrientes pela melancia em solo arenoso. Rev Ceres. 56: 112-118.

Word S, Esbensen K, Geladi P (1987) Principal component analysis. Chemometr Intell Lab Syst. 2: 37-52.

Yao Y, Xu G, Mou D, Wang J, Ma J (2012) Subcellular Mn compartation, anatomic and biochemical changes of two grape varieties in response to excess manganese. Chemosphere. 89: 150-157.

Zhao B, Yao X, Tian T, Liu X, Ata-Ul-Karim ST, Ni J, Cao W, Zhu Y (2014) New critical nitrogen curve based on leaf area index for winter wheat. Agron J. 106: 379-389.

Zheng Z, Li T, Zhang X, Yu H, Wang Y, Liu T (2014) Phosphorous accumulation and distribution of two ecotypes of Pilea sinofasciata grown in phosphorous-enriched soils. Appl Soil Ecol. 84: 54-61. 